\title{
POESÍA COMPLETA DE ERNESTO CARDENAL UNA BITÁCORA IMPRESCINDIBLE
}

Recibido: 20.01.2020/ Aprobado: 25.02.2020

Por Anastasio Lovo'

Nuestro querido Poeta y Sacerdote Ernesto Cardenal, partió a su encuentro con el Creador este 1 de marzo de 2020. Fue el más universal de nuestros poetas después de Darío. Cultura de Paz rinde homenaje a él, a su palabra, su ejemplo y su creación estética. Fue muy amigo y colaborador de nuestro Instituto Martin Luther King.

Ernesto Cardenal (Granada, Nicaragua 1925) sin duda alguna el poeta vivo más extraordinario de la lengua española y un formidable renovador de la poesía universal, acaba de publicar en Editorial Trotta de Madrid su Poesía Completa (2019). Esta magna obra ve la luz en forma de libro gracias a la edición de María Ángeles Pérez López, quien también presenta un excelente Estudio preliminar donde expone una bitácora del viaje cósmico de Ernesto Cardenal por las embravecidas galaxias de la poesía, el amor, la revolución, la mística, la cultura y la ciencia.

\section{Poesía Completa} de Ernesto Cardenal es un libro de 1228 páginas de papel mate en un formato de $24 \mathrm{~cm}$ por $14.5 \mathrm{~cm}$. Una obra colosal que no se habría podido concretar sin el concurso del mismo Padre Cardenal y su brillante, eficiente $y$ fiel asistente la pintora y poeta Luz Marina Acosta, quien a guisa de epílogo de la obra nos regala un bello poema en prosa titulado Al final donde en 26 líneas nos dice lo que significa Ernesto Cardenal y su poesía para ella.

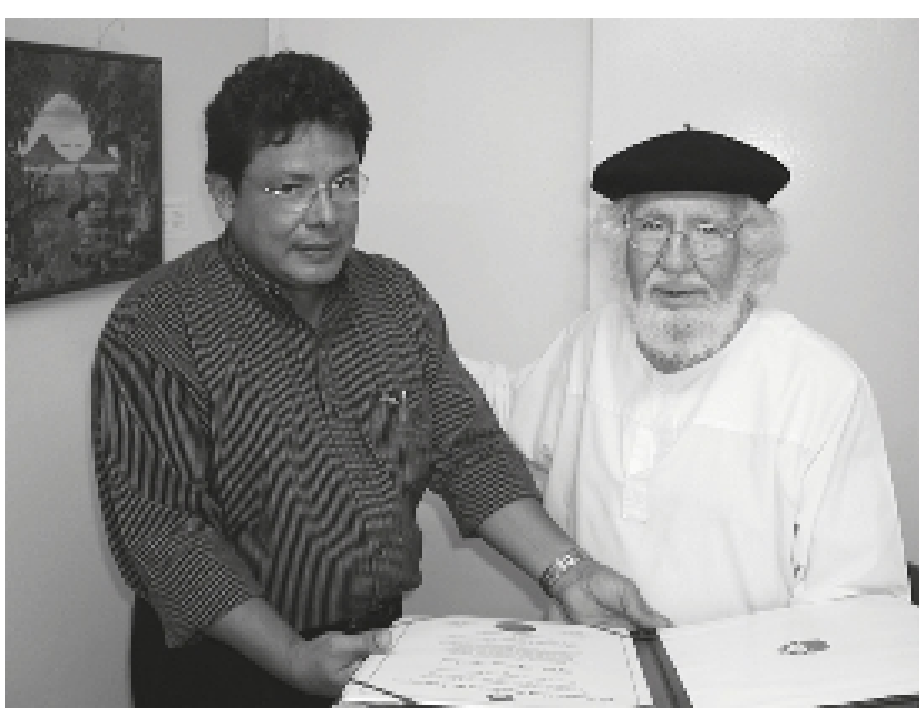

El Maestro Denis Torres, Director del Instituto Martin Luther King-UPOLI, en una visita al sacerdote y poeta Ernesto Cardenal, colaborador de la revista Cultura de Paz, le hace entrega de un diploma de reconocimiento (2004).
En su Estudio preliminar sobre la poesía de Cardenal, María Ángeles Pérez López desarrolla un interesante hilo cronológico evolutivo con valor taxonómico, que dará estructura a este volumen, sobre libros de poesía publicados, los temas abordados, las formas apropiadas y recreadas, los compromisos místicos de fe y políticos asumidos plena y consecuentemente por Cardenal en contextos históricos definidos y pertinentes para su ser poético. Toda una bitácora del peregrinar cristiano místico y cósmico de Ernesto Cardenal por nuestro mundo y el pluriverso.

Pérez López despliega su análisis en los siguientes acápites: Poemas documentales: testimonio $y$ lenguaje; La Hora 0; La poesía ante la llamada religiosa; El estrello dudoso: nueva épica de un pasado siempre presente; Solentiname: la voz del país y los poemas indios; La muerte de Thomas Merton; Canto nacional y Oráculo sobre Managua: los años convulsos; La poesía epistolar y el triunfo de la

1 Poeta, escritor y crítico de arte. 
revolución sandinista; Pasajeros de tránsito: los poemas de viajes; Cantar al cosmos desde la encrucijada de la ciencia; Telescopio en la noche oscura: plenitud del itinerario místico; Versos del pluriverso: erotismo y misticismo; Los hijos de las estrellas; "Otros poemas" en la obra cardenaliana y A modo de (incompleta) conclusión.

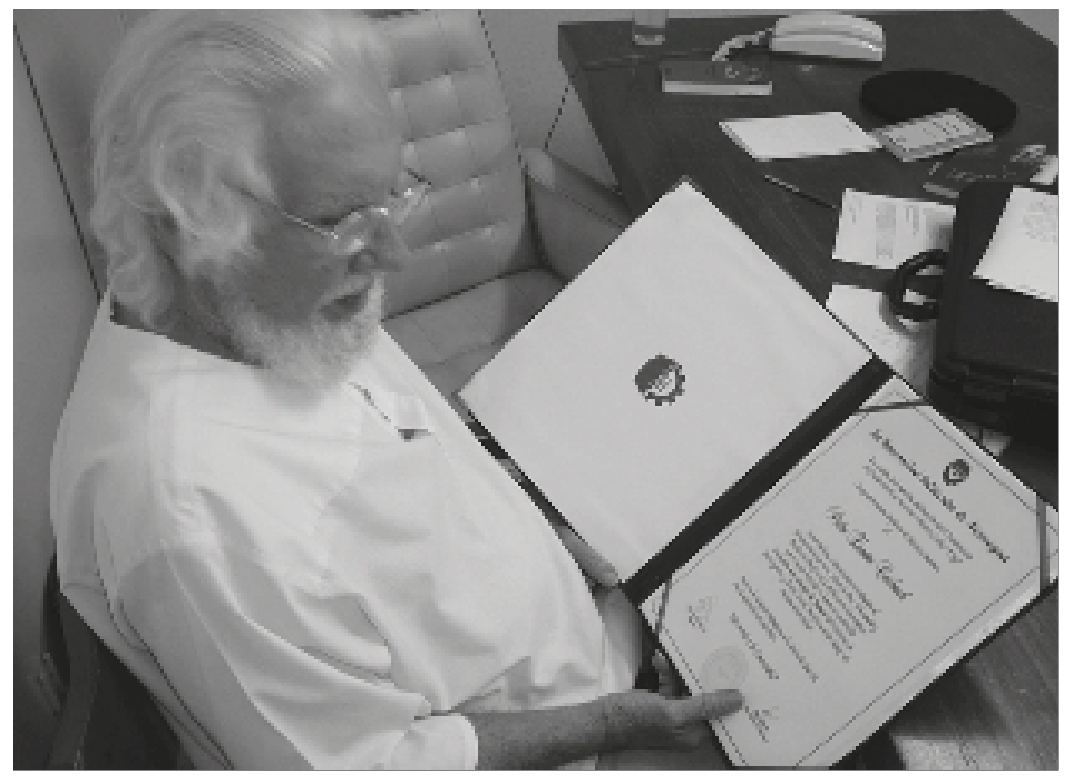

Pero en mi modesto entender la poesía de Ernesto Cardenal no tiene desperdicio. Sin lugar a dudas es absolutamente respetable su decisión de incluir lo que el libro contiene. El Padre Cardenal, junto a Ernesto Mejía Sánchez y Carlos Martínez Rivas, pertenecen a la magnífica generación de poetas nicaragüenses de 1940, una de cuyas

En el

Contenido (índice) del libro Poesía Completa de Ernesto Cardenal, se recogen en este orden los siguientes 18 libros: Epigramas, Poemas documentales, Hora 0, Gethsemani, Ky, Salmos, Oración por Marilyn Monroe y otros poemas, El estrecho dudoso, Los ovnis de oro (Poemas indios), Coplas a la muerte de Merton, Canto Nacional, Oráculo sobre Managua, Dos epístolas, Pasajero de tránsito (Poemas de viajes), Cántico cósmico, Telescopio en la noche oscura, Versos del pluriverso, Hijos de las estrellas y Otros poemas.

Un valor agregado extraordinario de esta obra es que en ella se plasma-al quedar impresala voluntad explícita de Ernesto Cardenal por legar y reconocer esta poesía como la que él quiso hacer para revolucionar las formas poéticas, compartir el pan de la mística cristiana no en fuga sino en encarnación histórica concreta, develar y revelar períodos de la historia de Nicaragua y Centroamérica, jugársela éticamente por una utopía política revolucionaria, volver al presente y resementizar la cultura de los aborígenes de estas tierras "americanas" haciendo realidad poética y símbolo de resistencia la visión de los vencidos y la extraordinaria hazaña poética inédita de realizar con poesía, mitología, historia, ciencia y sentido místico de trascendencia cristiana, la que debemos considerar la obra poética cumbre de nuestra lengua: Cántico cósmico. características es la rigurosidad con su economía verbal y lo éticamente exigentes que han sido con los textos que han publicado.

De ahí coligo que nos es aventurado creer que críticos y lectores de un presente y futuro inmediatos, leen y leerán como textos espléndidos aquellos que el Maestro Cardenal en esta ocasión ha excluido desde su vertical exigencia. Este libro también es la poesía de Ernesto Cardenal par lui meme, lo que evidentemente no lo agota. Ernesto Cardenal es de todos los seres humanos, es de nosotros, del amor, de las estrellas, del Cosmos, de Dios, porque así lo ha querido a lo largo de su fructífera vida.

Los nicaragüenses agradecemos a María Ángeles Pérez López, al Ministerio de Cultura y Deportes del Reino de España, a la Editorial Trotta que pongan en las manos y en los ojos de cada lector de poesía en lengua española, Poesía Completa de Ernesto Cardenal, un ayllu de donde parten y partirán muchos de los senderos, caminos y carreteras por donde transita y transitará la poesía universal.

Anastasio Lovo

Jinotepe, 17 de noviembre de 2019. 


\section{ECCE HOMO \\ Ernesto Cardenal}

No es que el hombre hubiera estado en él

(el Génesis antievolucionista)

sino que antes del hombre ya había paraíso.

Ireneo lo vio como un cambio perdido.

¡Un paraíso en perspectiva!

Sería que no logramos entrar en él.

Los primeros homínidos

(con la lujuriante selva tropical)

quedaron en los umbrales.

Todo primitivismo es una primera inocencia,

Como la de la niñez,

y una desnudez.

Isaías, Oseas, Zacarías,

profetizan el paraíso en el futuro.

Pecamos en Adán dice san Pablo. Los homínidos.

El hecho es que hubo una libertad. Que se usó.

Pero en Malmö vi con Daysi el largo muelle

en un Báltico con su azul de mayo

y cisnes en el mar, agua con algas,/

y al final del muelle

dos plataformas rigurosamente separadas,

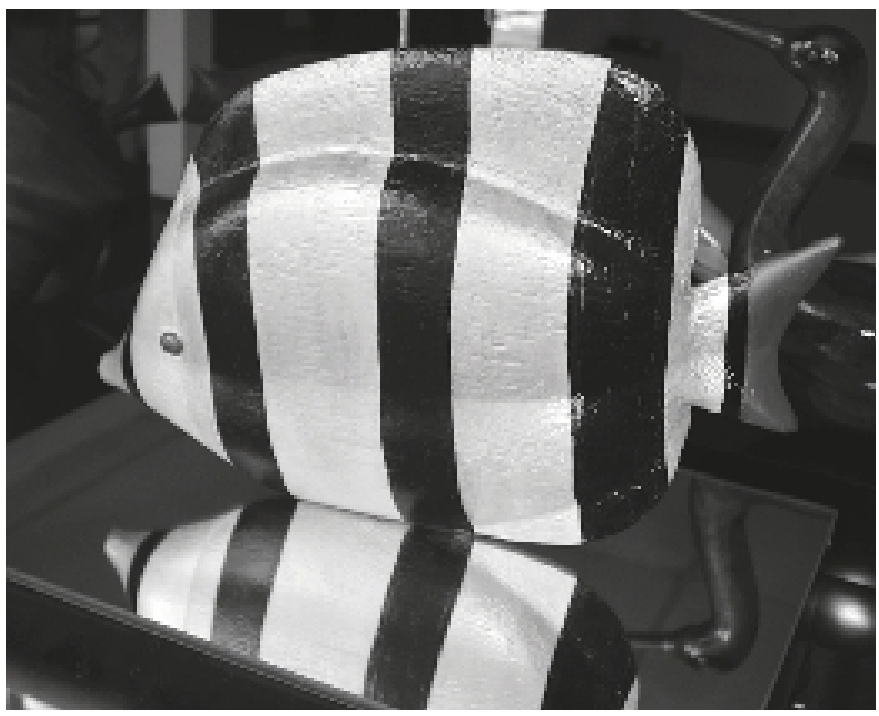

Autor: Ernesto Cardenal. Fotografía: Bondad de la Maestra Luz Marina Acosta.

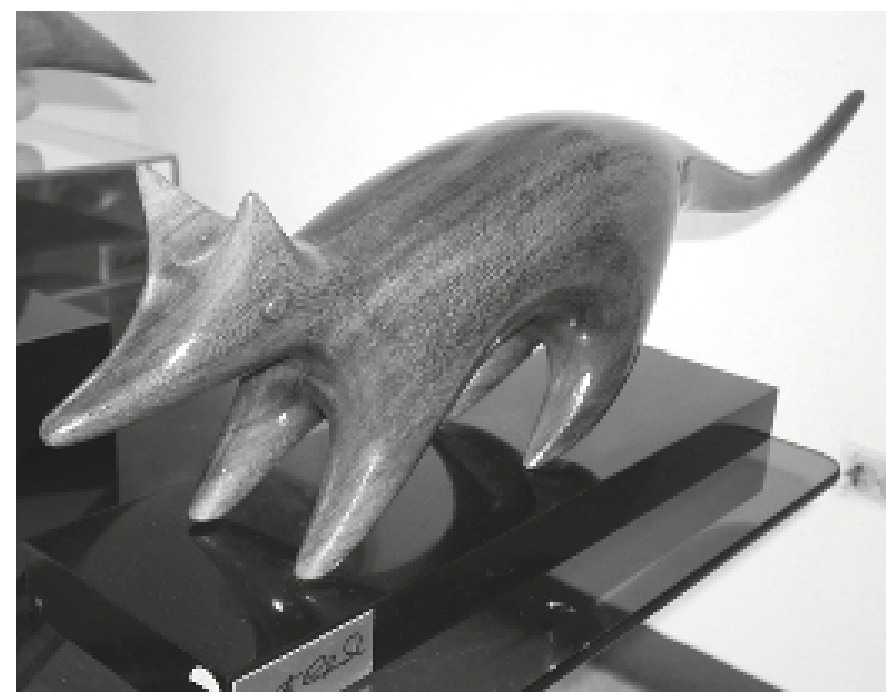

Autor: Ernesto Cardenal. Fotografía: Bondad de la Maestra Luz Marina Acosta.

una para los hombres desnudos asoleándose, en la otra las mujeres desnudas y solo los niños nadando escondidos podían verlas sacando del agua las cabecitas como peces, aunque los peces están también desnudos y no les da vergüenza:

Por qué la desnudez dio "vergüenza" no hay teólogo ni científico que lo explique.

Por qué no andamos desnudos,

Por qué striptease, revistas porno, Carnaval de Río, Pesadillas de estar desnudo uno en la calle. Ni el pasaje del Génesis lo explica. ¿Estás desnudas las palmeras y la garza? Pero la mujer bajo las palmeras está desnuda. La desnudez del Génesis sin hermenéutica todavía. ¿Se vieron desnudos? ¡Y qué...! ¿Será por el pecado original que andamos vestidos? A la orilla del Lago Turkana encontraron entre fósiles de homínidos

iel de una hoja de higuera! moldeada en el barro ahora petrificado una hoja de higuera. 


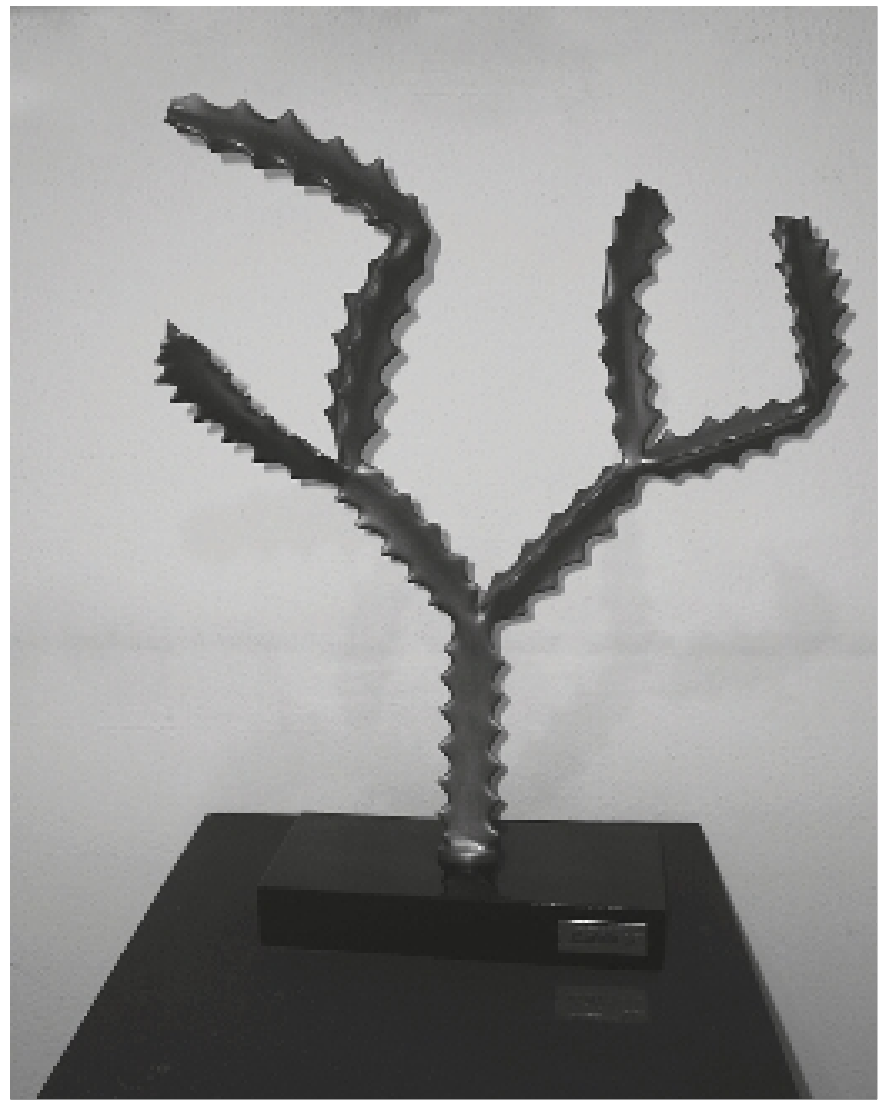

Autor: Ernesto Cardenal. Fotografía: Bondad de la Maestra Luz Marina Acosta.

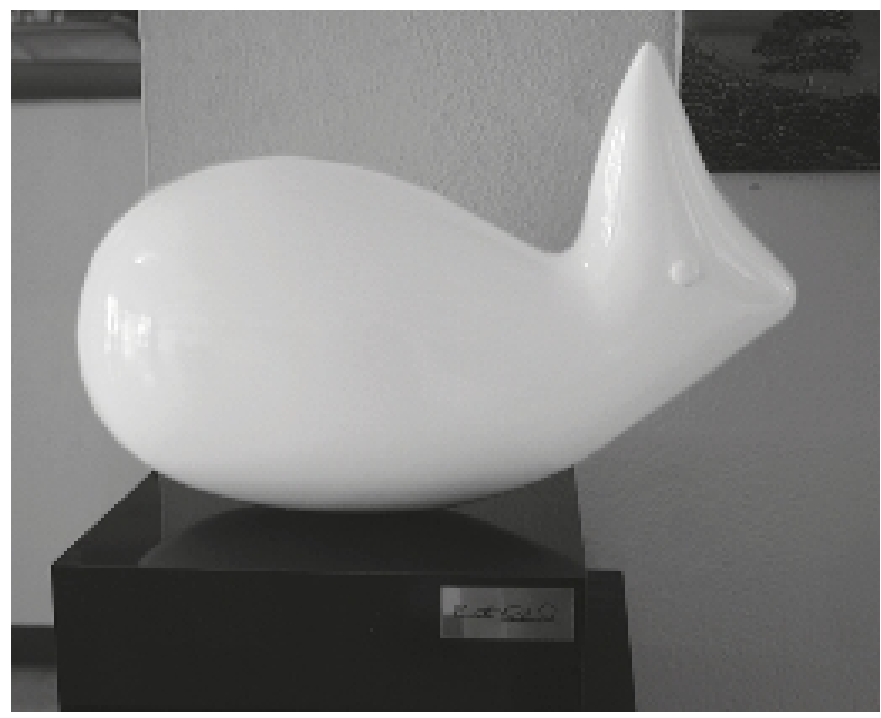

Autor: Ernesto Cardenal. Fotografía: Bondad de la Maestra Luz Marina Acosta.
Dicen que dejamos de tener pelo como los monos para estar más frescos bajo el sol tropical

y entonces fue que nos sentimos desnudos.

Y los pigmentos negros fue un pudor de la piel.

\section{Pero sea como fuere}

el Génesis no contradice El Origen de las Especies pues el paraíso

no es origen sino meta.

Meta original, digamos.

El planeta quedó lleno de piedras

y un homínido las usó.

Sílex contra sílex

y sale la flecha. cerebro,

Dos flechas: una formada dentro del/

la otra aún sin forma dentro del sílex.

El filo del pedernal quitó el de los colmillos.

Pero en la evolución del Hamo habilis no sería lo principalmente determinante la perfección de/ herramientas.

Muchos animales cazan juntos

pero no comparten lo cazado.

Cuando el mono compartió la comida ya no fue mono sino humano.

Dar y recibir: otra cosa que nos hizo humanos.

"La sobrevivencia del más apto".

Pero los más aptos son los más solidarios.

Comunión más que combate, dice Gould.

En aquellas selvas

no hubo ley de la selva.

El único animal en posición erguida.

Los brazos se acortaron

y se alargaron las piernas.

Hubo una capacidad física de andar en dos pies,

y una "ideología bípeda". 


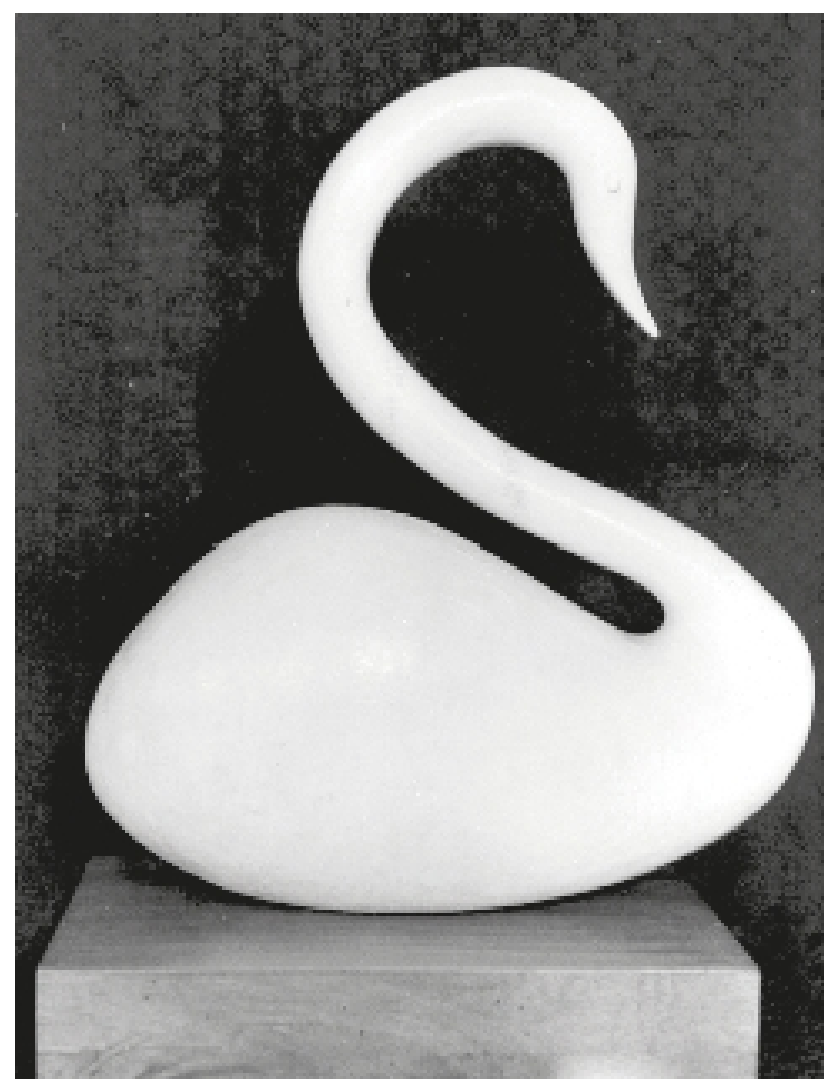

Autor: Ernesto Cardenal. Fotografía: Bondad de la Maestra Luz Marina Acosta.

El estar de pie nos hizo inteligentes, no ya un cerebro colgando de un cuerpo, sino sobre un espinazo vertical dominándolo todo; así se hizo más grande y con más frente.

4 veces más grande que el del mono por lo que la frente se hizo hacia adelante.

La mano ya no caminaba.

Mientras estaba más tiempo erecto usaba más sus manos.

Mientras usaba más sus manos

estaba más tiempo erecto.

El fuego también sirvió para juntarnos.

El fuego fue el lenguaje, las historias. La penúltima ramita de la evolución los neanderthales.
La última nosotros (hasta ahora). La manito apretada del bebé es por el pelambre que tenía la mamá.

Neanderthal ganó al sapiens físicamente pero no desarrolló los lóbulos frontales (los de la imaginación y de la ética, y también las/ emociones).

El único vertebrado que fue filósofo.

Hacía tiempo que la cola ya no era útil.

El fuego no solo fue útil sino fascinante.

Y todavía lo es. iNiños con fósforos!

Adultos ante las llamas de la chimenea.

Metimos el fuego en la cueva y fuimos hombres.

Del interior del bosque -algún árbol ardiendo.

Metimos el sol en la cueva y en derredor danzamos.

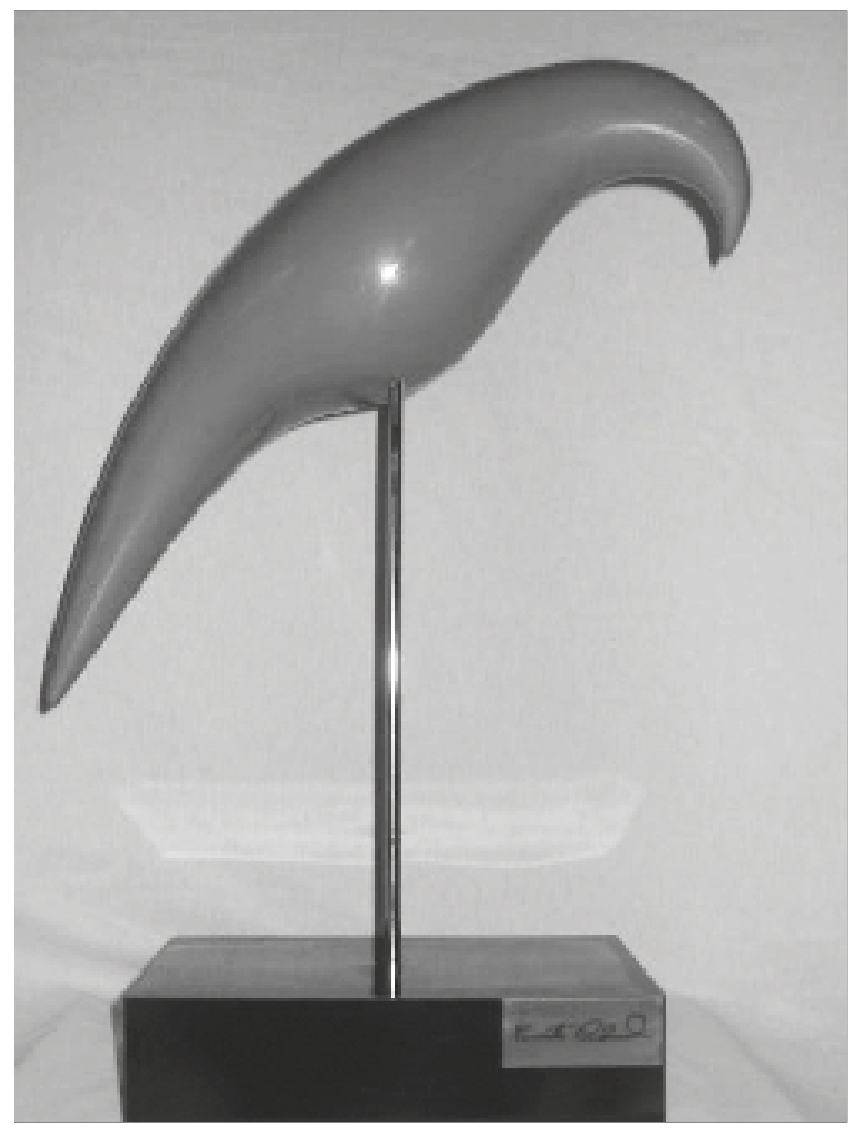

Autor: Ernesto Cardenal. Fotografía: Bondad de la Maestra Luz Marina Acosta. 


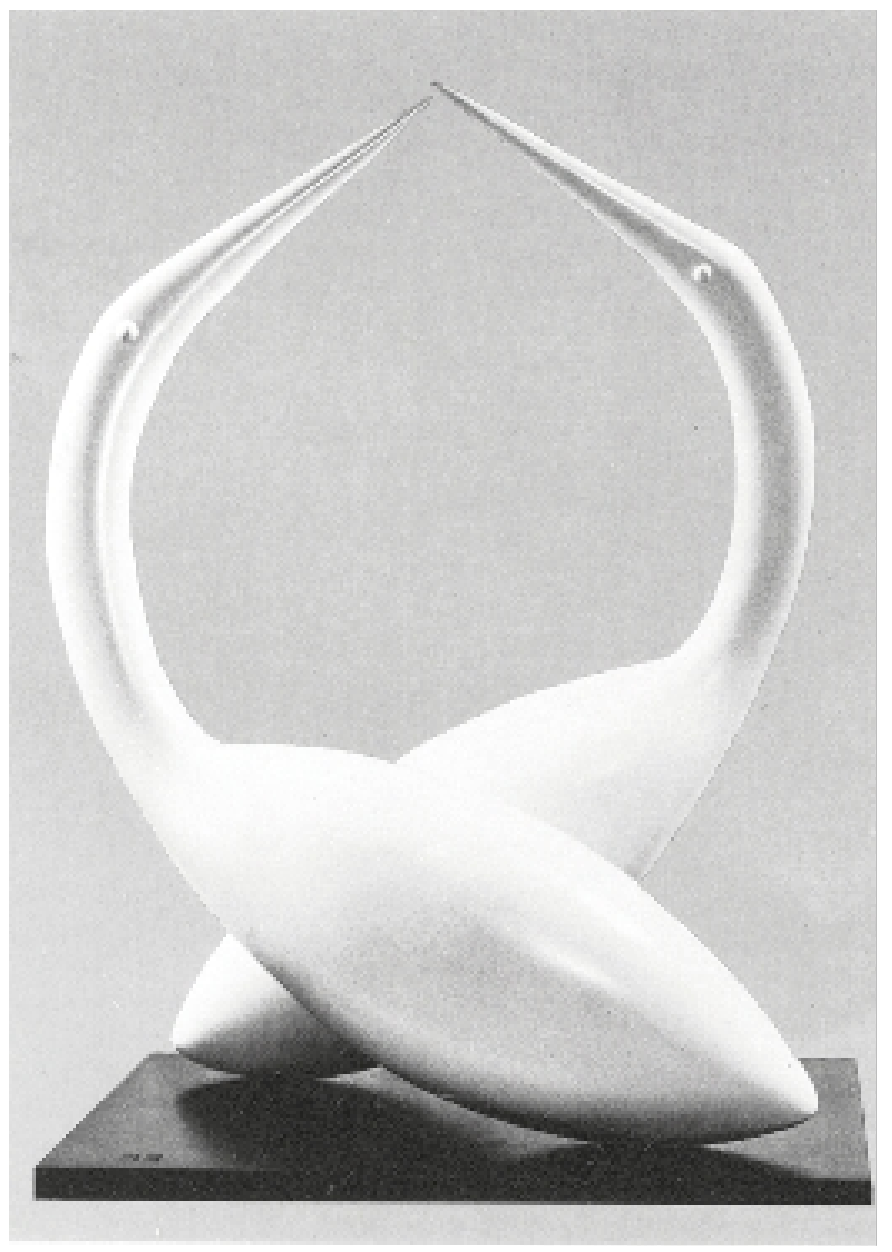

Autor: Ernesto Cardenal. Fotografía: Bondad de la Maestra Luz Marina Acosta.

"Como que una fuerza extraña escogió una especie/ afortunada".

El hombre es en grupo.

Solo existe el hombre como comunidad humana. Mientras tanto quedaron frustrados los delfines.

Aerodinámicos, por tanto sin mano derecha o/ izquierda.

Y en el agua, sin poder encender fuego.

El instinto que hay en los niños de trepar a los árboles ... Todavía no se sabe por qué nos pusimos en dos pies. Pero el ser erectos nos comprometió con el suelo, a ser ya exclusivamente terrestres.
Los dedos pudieron moverse separados, y el pulgar y el índice formar un círculo. Los ojos habían sido para la noche y eran grandes. Después fueron para el día y siguieron grandes pero ya fueron mirados los colores. Lo que en la selva monocroma fue ventaja: un mundo en colores, tridimensional y tocable, donde poder distinguir la fruta, cogerla y cortarla -y darla.

Separar lo concreto de su entorno.

Eso fue ya pensamiento. Y lenguaje.

Ver en colores se debe pues a las frutas maduras.

La curva hacia atrás sobre el lumbar hizo erecto al cuerpo y más bello también. Fue tal vez entonces que se sintieron desnudos. El sexo en mitad de sus cuerpos.

La fruta del conocimiento ético fue sabrosa. El Edén era en África.

Horno erectus: cuando ya fuimos hombres y no monos.

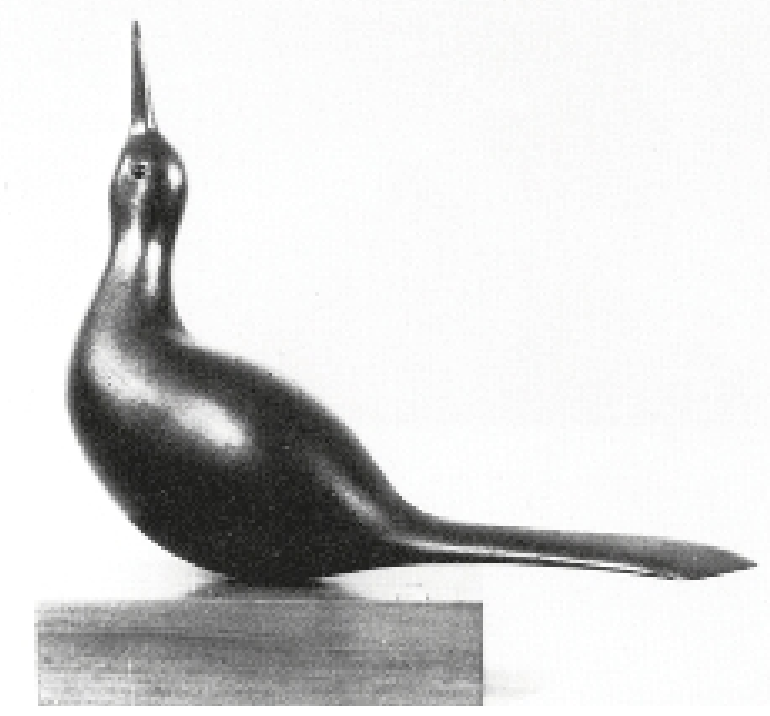

Autor: Ernesto Cardenal. Fotografía: Bondad de la Maestra Luz Marina Acosta. 


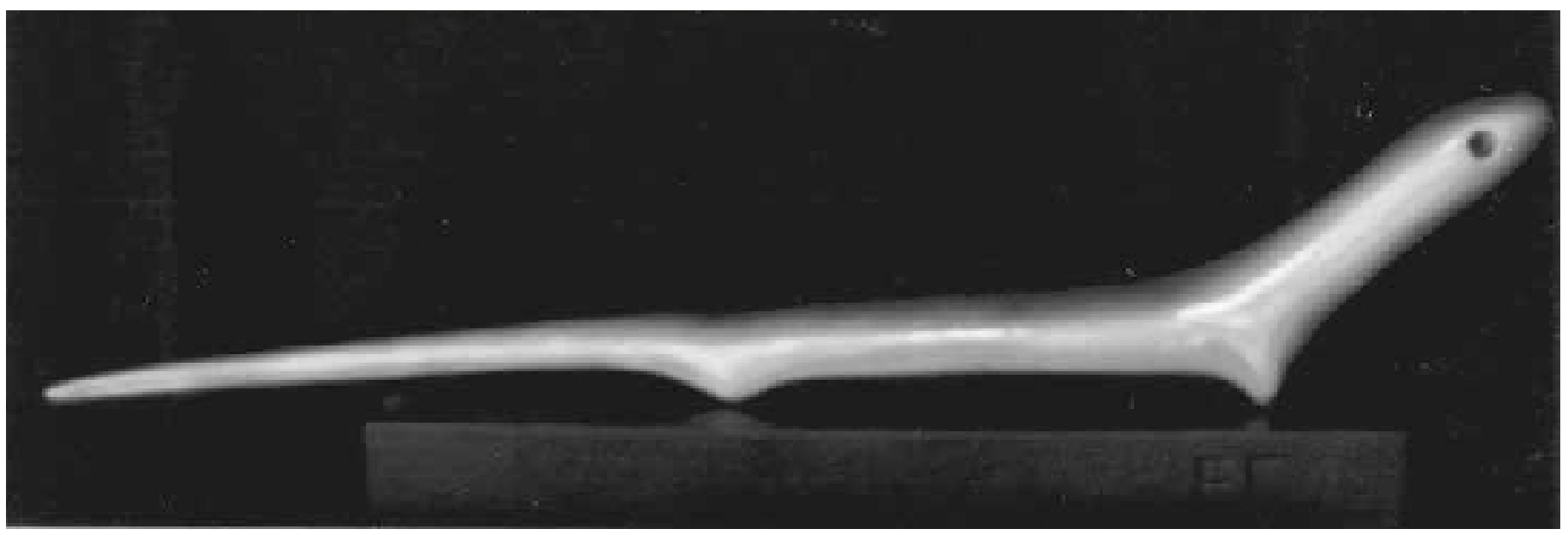

Autor: Ernesto Cardenal. Fotografía: Bondad de la Maestra Luz Marina Acosta.

El paraíso no fue dado sino ofrecido.

Al hombre y no al animal. El paraíso era el progreso no ofrecido al animal.

Miraron por eones las estrellas

con alguna regularidad y muchas irregularidades

y se preguntaban: ¿ Qué son ellas?

Más tarde aprendieron aritmética contando ovejas, aritmética que los llevó a contar galaxias.

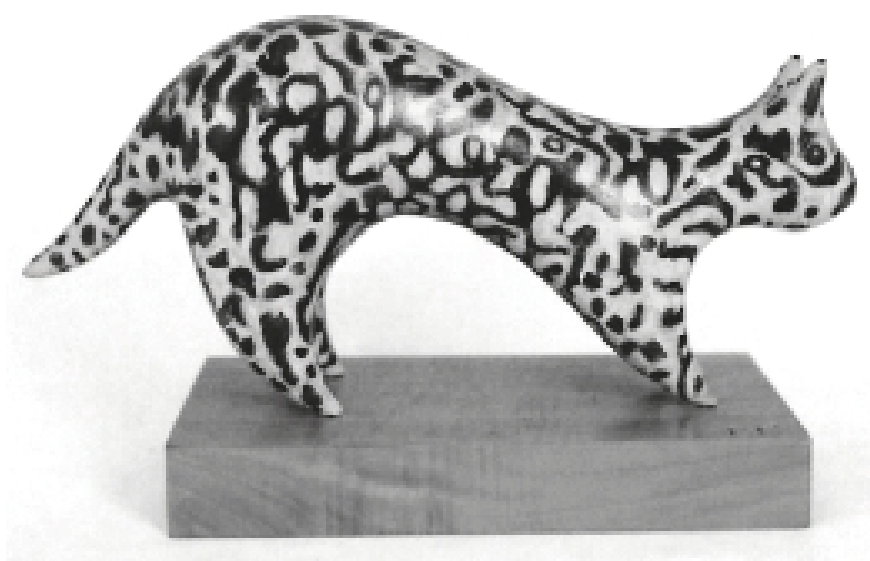

Autor: Ernesto Cardenal. Fotografía: Bondad de la Maestra Luz Marina Acosta.
El único animal con nalgas.

Y en posición erecta se le ocultó el ano.

La mujer único mamífero con mamas permanentes, y única hembra con orgasmo, y en celo todo el año. Para que hubiera en esas cuevas: un amor permanente.

El único animal que sonríe.

Los labios modificados para poder sonreír.

Separados de las encías, y así poder sonreír.

También la nariz se alargó

y la barbilla (ambas cosas para el lenguaje).

Los colmillos se atrofiaron

lo que nos cambió la cara y nos hizo hablar.

La lengua menos larga que en los monos,

eso también para hablar.

Primero sonidos simbólicos individuales,

que después fueron de todo el grupo.

El estar mucho tiempo juntos en la cueva

aumentó la comunicación.

Los monos menos humanos se perdieron en el monte.

¿̇El lenguaje nos hizo humanos

o el cerebro humano hizo el lenguaje? 
Comenzaron a tener ideas, nociones, la muerte por/ ejemplo.

El único animal que sabe que va a morir.

El lenguaje fue con fines prácticos primeramente, pero después pasó al mito y a cosas espirituales.

"Los riñones ya no solo para hacer orines sino también filósofos".

Domesticó plantas y animales

pero antes se domesticó a sí mismo.

El único animal vestido.

¿Los vestidos para ocultar la animalidad?

Sin pelambre más que en la cabeza,

por el sol,

y en el sexo, para resaltarlo.

Las nalgas muy juntas sin verse el ano.

Bellos ojos, labios, dientes, del Homo sapiens.

Evolución de una especie para dominar la/ evolución.

Otra diferencia con los animales: que somos/ responsables.

Otra diferencia también:

que somos para algo o para alguien.

"Un poco menor que los ángeles ... "- -dice el Salmo.

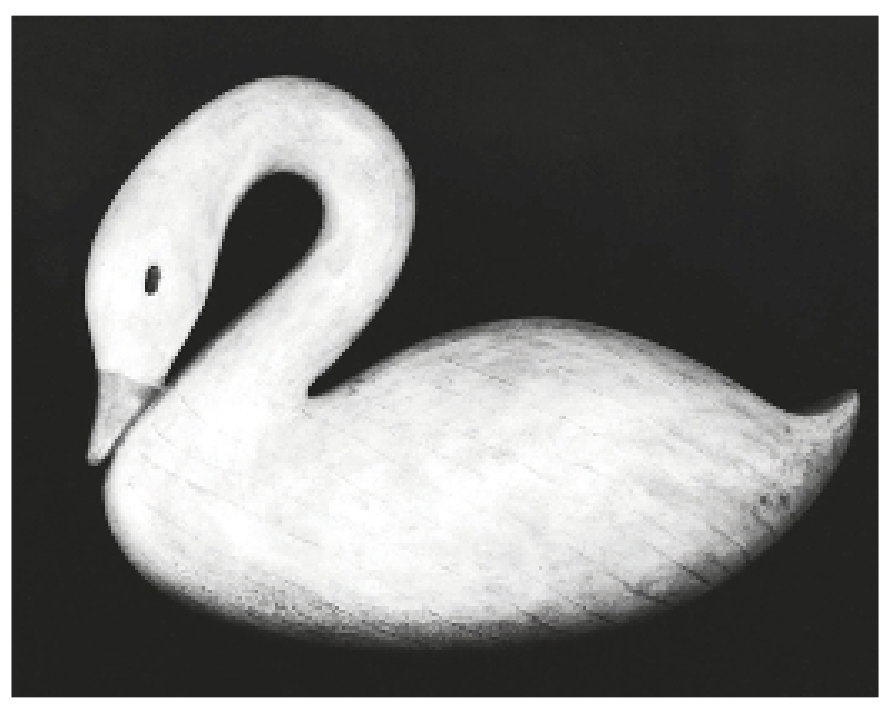

Autor: Ernesto Cardenal. Fotografía: Bondad de la Maestra Luz Marina Acosta.

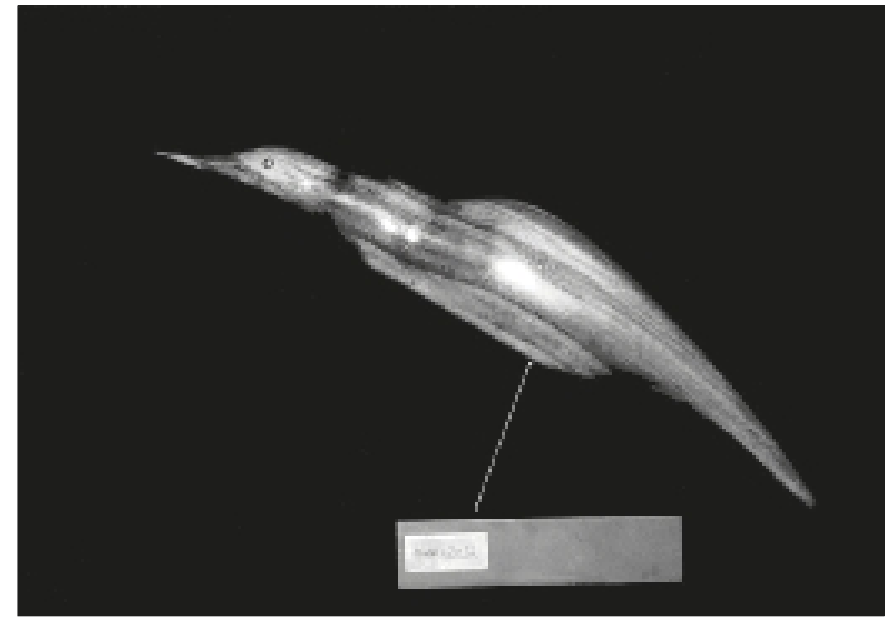

Autor: Ernesto Cardenal. Fotografía: Bondad de la Maestra Luz Marina Acosta.

¿Pero por qué con pedos y con intestino recto? Sus fósiles apenas se distinguen de los de otros/ animales.

Homo sapiens -ecce homo

Donde encarnó Dios. Lo que pasmaba a Tertuliano: ¿Dios sacado a luz por unas partes vergonzosas y alimentado de manera ridícula?

Todo cambio evolutivo fue para la sobrevivencia. Hasta nosotros.

Y siendo la más adaptable de las especies ¿no nos adaptaremos también tras la muerte? Fácil es concebirlo:

Una conciencia colectiva

cuyo cuerpo es el universo.

Sabe que va a morir. Para resucitar. Pero a morir. El único animal que llora cuando nace. 